\title{
Quality of work-life in employees experiencing a job-skill mismatch
}

\author{
Rifka Fadhiilah Arjuni, ${ }^{1}$ Aditya Nanda Priyatama, ${ }^{2 *}$ Pratista Arya Satwika ${ }^{3}$ \\ 1,2,3Psychology Department of Medical Faculty, Universitas Sebelas Maret, Surakarta - Indonesia
}

\begin{abstract}
Abstract: Quality of Work-life (QWL) in an employee is an important aspect to which a company needs to pay much attention, moreover if the employee experiences a job-skill mismatch. This study aimed to test the effect of job involvement and perceived happiness simultaneously and partially on the quality of work-life in an employee who experiences a job-skill mismatch. The instruments used for collecting data were the QWL scale, job involvement scale, and perceived happiness scale. The subjects of this study were 64 employees. The method of data analysis was the multiple regression analysis. The result of this study showed that job involvement and perceived happiness simultaneously affected QWL $(r=0,763$; $\mathrm{p}=0,000)$. Partially job involvement also had an effect on QWL $(r=0.64 ; \mathrm{p}=0,000)$ and perceived happiness on QWL $(r=0,261 ; p=0,039)$. Simultaneously, the contribution of job involvement and perceived happiness to the QWL of the employees with a jobskill mismatch was $56.9 \%$. It means that the higher the rate of job involvement and perceived happiness, the higher the quality of work-life an employee with a job-skill mismatch has, and vice versa.
\end{abstract}

Keywords: job involvement; job-skill mismatch; perceived happiness; quality of work-life

\begin{abstract}
Abstrak: Quality of work-life (QWL) pada karyawan merupakan aspek penting yang perlu diperhatikan perusahaan, terlebih lagi jika karyawan tersebut mengalami jobskill mismatch. Tujuan penelitian ini untuk menguji secara simultan pengaruh job involvement dan perceived happiness terhadap quality of work-life pada karyawan yang mengalami job-skill mismatch. Penelitian juga bertujuan untuk menguji pengaruh job involvement terhadap QWL dan pengaruh perceived happiness terhadap QWL secara parsial. Penggalian data menggunakan skala quality of work-life, skala job involvement, dan skala perceived happiness. Subjek penelitian ini karyawan yang mengalami job-skill mismatch, yang berjumlah 64 orang. Metode analisis data menggunakan analisis regresi berganda. Hasil penelitian menunjukkan pengaruh job involvement dan perceived happiness terhadap QWL $(\mathrm{r}=0,763 ; \mathrm{p}=0,000)$. Sementara, secara parsial job involvement juga berpengaruh terhadap QWL $(\mathrm{r}=0,64 ; \mathrm{p}=0,000)$. Selain itu, perceived happiness juga memiliki pengaruh terhadap QWL $(\mathrm{r}=0,261$; $\mathrm{p}=0,039$ ). Secara bersamaan kontribusi job involvement dan perceived happiness terhadap QWL sebesar 56,9\% pada karyawan yang mengalami job-skill mismatch. Artinya, semakin tinggi job involvement dan perceived happiness maka semakin tinggi pula quality of work-life karyawan dengan job-skill mismatch, begitu pula sebaliknya.
\end{abstract}

Kata Kunci: keterlibatan kerja; ketidakcocokan pekerjaan-keterampilan; kebahagiaan yang dirasakan; kualitas kehidupan kerja

\footnotetext{
*Corresponding Author: Aditya Nanda Priyatama (e-mail: adityanandapriyatama@gmail.com), Psychology Department of Medical, Faculty Universitas Sebelas Maret, Jl. Ir. Sutami No.36 A, Kota Surakarta, Jawa Tengah 57126, Indonesia.
} 


\section{Introduction}

The era of globalization has made it easier for people to look for jobs. According to the data posted on the official website of Badan Pusat Statistik (2017), the percentage of open unemployment rate in Indonesia reached 5.33\%, showing a decrease from the last year's rate. However, the mismatch of competencies in manpower in companies still recorded a high rate of $63 \%$ according to the Minister of Manpower, Hanif Dhakiri (Mardiana, 2017).

Based on the data, it could be concluded that the need for a company or organization for human resources with certain qualifications is not always well fulfilled. The mismatch between jobs and competencies possessed by the existing population of manpower becomes one of the causes of job-skill mismatch.

According to the International Labour Organization's data issued in May 2017, job-skill mismatch is the level of skill of an individual that does not match the skill needed in his/her job, and such a condition occurs in the manpower market. The measurement of job-skill mismatch can be grouped into two categories, namely vertical mismatch and horizontal mismatch. The former refers to the mismatch between the level of education and job (over education or under education), and the latter refers to the mismatch between the field of education and work despite the level of education meeting the qualification of the work (Comyn, 2017).

The mismatch in the issue of manpower certainly has a significant effect on the company that has hired an individual who does not fit the job offered as its employee. Many individuals choose their education without having definite planning about what will be done and worked in the future.
Many individuals do not realize that later education they have chosen will support the progress of their careers. Bender and Roche (2013) stated that a mismatch between education and occupation causes low income and work satisfaction, as well as a high rate of turnover, which eventually affects work productivity. Therefore, a company needs to maintain its work environment and make its employees have a good perception of work welfare, experience, and needs, especially the employees experiencing job-skill mismatch.

The theory related to worker's perception of the working atmosphere and experience at the workplace is called quality of work-life theory. According to Lau and May (1998), it is a worker's view or perception of a good condition and environment of workplace that supports the worker's satisfaction through the presence of respect, security, and opportunity to develop in working.

The issue of quality of work-life is a challenge for every company to keep improving its support to its employees. The different backgrounds and needs of employees force a company as optimal as possible to be able to facilitate the fulfillment of their needs, moreover, if the company has employees with extra needs, such as those with a job-skill mismatch.

According to Warr, Cook, and Wall (1979), there are eight relevant factors related to the quality of work-life i.e. job involvement, intrinsic job motivation, higher-order need strength, perceived intrinsic job characteristics, happiness, life satisfaction, job satisfaction, and self-rated anxiety.

One of the internal factors relevant in affecting the quality of work-life is job involvement. It is how much an individual engages in his/her work. It refers to the identification of work interest and an 
important aspect of an individual's psychological involvement with his/her work. It can be concluded that job involvement is an individual's involvement with his/her work both physically and emotionally.

Several previous studies have proven that job involvement has a strong effect on the quality of work-life of company workers. Fuadi's study (2013) with a sample of 187 people working at the Aceh Education Office, stated that the fulfillment of compensation, the creation of a good work environment, and the involvement of employees in work succeeded in creating a quality work-life. Among these three factors, employees' job involvement showed the strongest positive relationship.

Job involvement becomes one of the factors of the emergence of quality of work-life because individuals will feel a quality work-life when they are involved in the work. Employees' involvement can make them assess and evaluate the quality of work-life so that job involvement becomes important for creating a quality of work-life for employees.

Besides being influenced by job involvement, quality of work-life is also influenced by other internal factors, namely happy feelings or perceived happiness (Warr et al., 1979). Perceived happiness is an individual's perception of the happiness they feel. Happiness is a state of human psychological well-being (Pettijohn \& Pettijohn, 1996). The happy feeling of every individual in all aspects of their life would greatly encouragement for them to play an active role and do the best in their works. This will have a positive impact on their performance, which also provides a large profit for the company. Happiness can be interpreted as an experience that brings positive influence and rarely brings negative influence. As a whole, it is a form of satisfaction and well-being (Meyers \& Diener, in Dasgupta, 2010).
Every individual also has different factors to be able to bring happiness so that they can perceive themselves that they feel happy (Seligman, 2005). Perceived happiness in employees is important for the company so that the productivity, performance, and work environment in the company has a positive value. Perceived happiness has an important role in determining its relation to the quality of work-life.

Based on the research conducted by Warr et al., (1979), happiness is one of the factors creating quality of work-life. The happy feeling meant is the happiness felt by every individual in general regarding the quality of their lives, which affects the quality of their work-life. Other research conducted by Danna and Griffin (1999) also explained that job satisfaction is a reflection of an individual's happiness that later becomes one of the concepts that affect the quality of work-life so that employees who are satisfied with their lives will naturally feel happier in doing their jobs, they also have a good view of the quality of work-life.

Internal factors such as employees' happiness are one of the things that every company needs to pay attention to within the phenomenon of jobskill mismatch. Happy individuals will have a positive view of what they experience so that they have a quality of work-life that tends to be good. The mismatch that occurs between educational background and work can be a challenge for an employee to get new competencies. High adaptation and ability to manage emotions is needed, considering that an inner conflict felt occurs due to job mismatch.

The phenomenon of job-skill mismatch was not uncommon in many companies in Indonesia, one of which was PT. X where the study was done. At that company, 74 employees worked not following their educational backgrounds or later referred to as horizontal job-skill mismatch. Although the company provided training and 
programs to increase the skills and expertise of its employees, there were still many employees who experienced job-skill mismatch who seemed to be less satisfied with their works and found it difficult to work optimally.

Based on the results of the interviews conducted by the researchers with 4 employees who experienced job-skill mismatch, 3 of them said that for the first time they experienced jobskill mismatch. Broadly speaking, the three employees still needed to adapt to their work, sometimes also found it difficult or a little slow to do their jobs. One of the employees who experienced job-skill mismatch stated that after working, he did not feel comfortable with his work and felt not entirely comfortable with the work environment so that the desire to quit the job had ever crossed his mind.

The employees felt the working environment was not good and not supportive. The inconvenience they experienced sometimes became their reason for being reluctant to participate in the company's activities so that they were less involved. Besides, the four employees interviewed also said that sometimes they felt burdened with new competencies they had to learn. They felt that their career opportunities would not develop. One employee also said that the facilities and career programs and training provided by the company were very important to help adapt to the work, but sometimes the training was still inadequate for the employees who experienced job-skill mismatch like him because the company provided the same training and coaching at every level of employees while employees with job-skill mismatch should get more training to balance their competencies. This made them feel dissatisfied with the competency development facilities of the company. Indirectly, the employees showed feelings of dissatisfaction and felt the low quality of work life.
Based on the phenomenon and elaboration above, the researchers proposed three hypotheses, i.e. a) there is an effect of job involvement and perceived happiness on the quality of work-life of employees who experience job mismatch skills, b) there is an effect of job involvement on the quality of work-life on employees who experience jobskill mismatch, and c) there is an effect of perceived happiness on the quality of work-life on employees who experience job-skill mismatch.

\section{Method}

The subjects of this study were all employees of PT X, who experienced horizontal job-skill mismatch. The number of employees was 64 people. A horizontal job-skill mismatch means that employees whose educational backgrounds do not fit their jobs.

The selection of the subjects used a saturated sampling technique so that the sample involved the entire population of the PT.X's employees with a horizontal job-skill mismatch. Seventy-five employees were experiencing job-skill mismatch. However, the researchers used 64 of them only because the 11 others were declared administratively fallout. They did not agree to fill in the research scale.

Before the scale was used in extracting the research data, the researchers first conducted a validity and reliability test. This validity test aimed to discover how precisely the measuring instrument could measure the attributes that should be measured. This validity test used the correcteditem total correlation (Azwar, 2013). Successively, the reliability test used internal consistency with the Cronbach's Alpha technique. The scale in a measurement is said to be reliable if it has a Cronbach's Alpha value $\geq 0.6$ (Azwar, 2012).

The quality of the work-life scale was adapted and modified from the work-related quality of life scale formulated by Easton and Laar (2013). It 
consisted of 20 favorable items and 3 unfavorable items. Based on the result of the validity test, 6 items were declared null and 17 items were valid with the reliability coefficient of 0.881 .

The job involvement scale was composed by the researchers based on the aspects of job involvement suggested by Lodahl and Kejnar (1965). It consisted of 15 favorable items and 10 unfavorable items. Based on the result of the validity test, there were 4 items declared null and 21 valid with the reliability coefficient of 0.899 .

The perceived happiness scale was composed by the researchers based on the aspects of the perceived happiness of Lyubomirsky \& Lepper (1999). It consisted of 8 favorable items and 4 unfavorable items. Based on the validity test, there were 3 items declared null and 9 items valid, with the reliability coefficient of 0.708 .

Researchers tested the basic assumptions before testing the hypothesis. The basic assumption test consisted of a normality test and a linearity test. This study used multiple regression analysis as a data analysis method to test the research hypotheses. Multiple regression analysis was used to determine the effect of the quality of work-life and job involvement variables on perceived happiness. Besides, researchers also conducted a partial correlation test to determine the effect of each independent variable on the dependent variable.

\section{Results}

This study used the One-Sample KolmogorovSmirnov Test as the normality test method with the condition if the significance value is more than 0.05 , it means the data is normally distributed (Santoso, 2014). The calculation results showed the significance value of the three variables, namely quality of work-life $(p=0.086)$, job involvement $(p=0.176)$, and perceived happiness $(\mathrm{p}=0.200)$. All the three data had $\mathrm{p}>0.05$, meaning that the three variables were normally distributed.

Then, the next test was the linearity test. It was to find out whether there was a linear relationship between the two research variables. Two variables are said to be linear if the significance value or $\mathrm{p}<0.05$ (Santoso, 2014). The calculation results showed the significance value between the quality of work-life and job involvement was 0,000 and the significance value of quality of work-life and perceived happiness was 0,000 ( $p<0.05$ ), it could be concluded that there was a linear relationship between quality of work-life and job involvement and between the quality of work-life and perceived happiness.

This study used a hypothesis test in the form of multiple linear regression analysis. Then, it used the $\mathrm{F}$ simultaneous test to prove whether the proposed research hypothesis can be accepted or rejected (Santoso, 2014). If the significance value is smaller than 0.05 and the value of $F_{\text {count }}>F_{\text {table, it }}$ can be concluded that the independent variables simultaneously influence the dependent variable (Santoso, 2014).

The results showed that the first hypothesis of this study was acceptable. Table 1 shows the $\mathrm{F}_{\text {count }}$ value was greater than $F_{\text {table, which was } 42.518>}$ 3.15 with a significance value of 0.000 or less than 0.05 . So, it could be said that job involvement and perceived happiness together had a significant effect on the quality of work-life for the employees who experienced job-skill mismatch.

Table 2 shows the multiple correlation coefficient of 0.763 so that it can be said that the correlation between job involvement and perceived happiness with the quality of work-life was strong. Then, the adjusted R2 or adjusted determination coefficient value was used to determine 
the contribution of the independent variable to the dependent variable simultaneously. The figure of the adjusted determination coefficient would then be changed in the form of a percentage, which means the percentage of the contribution of the influence of the independent variable on the dependent variable (Priyatno, 2012).

Based on the adjusted R2 value, it could be concluded that the job involvement and perceived happiness variables jointly contributed to the effect of quality of work-life on employees who experienced job-skills mismatch of $56.9 \%$, while the remaining $44.1 \%$ were contributed from other factors outside the variables used by researchers.

A partial correlation test was conducted to find out whether the proposed hypothesis was accepted or rejected by looking at how the independent variable regression model partially has a significant effect on the dependent variable (Santoso, 2014). Based on the calculation results, the correlation value between job involvement and quality of work-life was 0.64 with a significance of $0,000(p<0.05)$. The significance value of less than 0.05 indicated a significant correlation between the quality of work-life and job involvement. While the correlation value of
0.64 indicated a positive correlation that was classified as strong between the two variables. These results showed that there was an effect of job involvement on the quality of work-life of the employees who experienced job-skill mismatch significantly so that the second hypothesis of this study could be accepted.

Furthermore, the correlation value between perceived happiness and quality of work-life was 0.261 with a significance of $0.039(\mathrm{p}<0.05)$. The significance value of less than 0.05 indicated a significant correlation between perceived happiness and quality of work-life. While the correlation value of 0.261 indicated a positive but relatively weak correlation. These results showed that there was a significant influence of perceived happiness on the quality of work-life in the employees with a job-skill mismatch so that the third hypothesis in this study could be accepted.

Descriptive analysis results of this study showed a mean quality of work-life of 51.58 (SD = 5.589), mean job involvement of 66.47 (SD = 7.259), and mean perceived happiness of 29.25 ( $\mathrm{SD}=3.409)$.

Table 1.

The Result of Simultaneous Test F

\begin{tabular}{llrrrrr}
\multicolumn{7}{c}{ ANOVA $^{\mathrm{a}}$} \\
Model & Sum of Squares & $\mathrm{df}$ & Mean Square & $\mathrm{F}$ & \multicolumn{1}{c}{ Sig. } \\
\hline \multirow{2}{*}{1} & Regression & 1145.732 & 2 & 572.866 & 42.518 & $.000^{\mathrm{b}}$ \\
\cline { 2 - 7 } & Residual & 821.878 & 61 & 13.473 & & \\
\cline { 2 - 7 } & Total & 1967.609 & 63 & & & \\
\hline
\end{tabular}

Table 2.

The Result of Model Summary

\begin{tabular}{lccrrrr}
\multicolumn{7}{c}{ Model Summary $^{\mathbf{b}}$} \\
\hline Model & $\mathrm{R}$ & R Square & Adjusted R Square & $\begin{array}{c}\text { Std. Error of the } \\
\text { Estimate }\end{array}$ & Durbin-Watson \\
\hline 1 & $.763^{\mathrm{a}}$ & .582 & .569 & 3.671 & 1.748 \\
\hline a. Predictors: (Constant), PH, Jl & & & & &
\end{tabular}


b. Dependent Variable: QWL

Descriptive analysis results of the categorization of quality of work-life showed that as many as $3.12 \%$ of the respondents belonged to the low category, $14.06 \%$ in the medium category, and $67.18 \%$ with a high category, then $15.62 \%$ were classified as very high.

The results of the descriptive analysis on the categorization of job involvement showed that $1.56 \%$ of the respondents belonged to the low category, $7.81 \%$ to the medium category, $67.18 \%$ to the high category, and $23.43 \%$ to the very high category.

The results of the descriptive analysis on the categorization of perceived happiness showed that $9.37 \%$ of the respondents belonged to the medium category, $56.25 \%$ to the high category, and $34.37 \%$ to the very high category.

Subsequently, based on the calculation of the effective contribution (EC) of job involvement to the quality of work-life was $47.12 \%$. The effective contribution of perceived happiness to quality of work-life was $11.10 \%$. The total contribution of job involvement and perceived happiness to quality of work-life was shown by the adjusted $\mathrm{R}$ Square value of 0.569 or $56.9 \%$, while $43.1 \%$ of the creation of quality of work-life was influenced by other variables outside this study.

\section{Discussion}

The results of this study indicated that the first hypothesis was acceptable, namely that job involvement and perceived happiness affected the quality of work-life in employees who experience job-skill mismatch. Both independent variables also had an effective contribution to the dependent variable by $56.9 \%$,

Research conducted by Warr, et al (1979) explained that among several variables studied, it was found that the variables of job involvement and perceived happiness had a significant correlation with the quality of work-life. Work environment which is one of the aspects of quality of work-life can be created by the behavior and psychological condition of employees in carrying out their works, one of the behaviors is the involvement of employees in work. This reflects that the level of employee involvement can determine the quality of work-life (quality of work-life) felt by the employee (Cascio, 1982).

The intended involvement is not only about employee attendance, but also about how the employee desires to do the job as possible (Warr et al., 1979). The happiness that is reflected in the well-being of employees' lives also affects the individuals' perspectives on the quality of their work. It also turned out to be following the results of this study, that employees' involvement and happiness felt by job-skill mismatch employees also affected their quality of work life.

Kaur (2016) added that one of the things that can be done by employees to improve the quality of work-life is by engaging in work like giving an opinion, giving ideas or input, and participating in making decisions. Based on the results of this study, most of the employees with a job-skill mismatch who were actively involved in the activities held by the company could feel that their quality of work-life are high quality because they can judge that the company provided what they needed.

The results of this study stated that although the employees had jobs different from their educational backgrounds, they could still work optimally and the quality of work-life was good. Oshagbemi (1999) said that happiness perceived by adults about their lives will affect the way they look at the quality of their work-life because adults spend most of their time working. This is following 
the results of this study which stated that the happiness of employees who experience job-skills mismatch related to all aspects of their lives can also affect the level of quality of work life. This study proved that job involvement and perceived happiness together affect employees' quality of work-life, which means that the more employees are involved and the better level of employees' happiness in all aspects of life, the more they can affect the creation of quality of work-life.

The researchers also conducted a partial correlation test on the independent variable to see the effect of each independent variable on the dependent variable. The result was a positive and strong relationship between job involvement and quality of work-life so that the second hypothesis of this study could be accepted. The direction of the positive correlation indicates that the higher the job involvement, the higher the quality of work-life experienced, and vice versa.

Job involvement becomes one of the factors that influence the creation of quality of work-life because employees who experience work involvement will be able to assess how they experienced the quality of work-life (Warr et al., 1979). Study on the factors of compensation, work environment, and job involvement states that of the three factors, job involvement shows the strongest influence on the quality of work-life (Fuadi, 2013).

The results of this study are supported by previous studies which state that job involvement influences the creation of quality of work-life. In this study, although employees experienced a jobskill mismatch, the level of quality of work-life was fairly high because they had a high desire to be involved in their work. They could assess that the company had provided facilities and fulfilled their needs as employees with job-skill mismatch by providing appropriate coaching and training.
The mismatch between job and educational background of the employees allowed them to develop new skills which then made them able to develop and work optimally.

Then, it was also found that there was an effect of perceived happiness on the quality of work-life so that the third hypothesis of this study could be accepted. The direction of the positive correlation indicated that the higher the perceived happiness, the higher the quality of work-life experienced, and vice versa.

The happiness that is felt by individuals influences their quality of work-life (Warr et al., 1979). Dasgupta's research (2010) also stated that individuals with a good ability to regulate emotions can create happiness so that every aspect of their life has better quality. One aspect that is also affected is in their jobs. Therefore, the study concluded that happiness has a positive correlation with the quality of work-life.

The results of this study indicated that the level of happiness in the employees with job-skill mismatch skills was so high, that it caused a high level of quality of work life. Danna and Griffin (1999) said that an individual's welfare, in general, reflects their happiness, which then becomes one of the concepts of the creation of quality of worklife.

In the results of this study, although the employees with a job-skill mismatch had different educational backgrounds from their jobs, most of them had a high level of happiness. The high level of happiness in all aspects of employees' lives can occur due to external factors such as social support, welfare, health, marriage, and religiosity. The feelings of happiness and positive thoughts of employees towards their lives, make them feel that their work-life is of good quality or, in other words, has a good quality of work-life. 
The categorization of the level of quality of work-life in this study showed that most of the employees who experienced a job-skill mismatch had a high level of quality of work-life (67.18\%). Furthermore, the categorization of the level of job involvement in the majority of the employees who experienced a job mismatch skills had a high level of job involvement (67.18\%). Meanwhile, the categorization of the level of perceived happiness in the majority of employees who experienced a job-skill mismatch had a relatively high level of perceived happiness too (56.25\%).

\section{Conclusion}

This study could conclude that job involvement and perceived happiness all together have a significant effect on the quality of work-life in employees who experience a job-skill mismatch. Besides, the job involvement of employee who experiences a job-skill mismatch significantly affected their quality of work-life. Thus, the higher the job involvement of employees, the higher the quality of work-life they had. The results of this study also indicated that there is a significant effect of perceived happiness on the quality of work-life in employees who experience job-skills mismatch. Thus, the higher the perceived happiness of employees, the higher the quality of work-life they had.

Based on the results of this study, the effective contribution concurrently was given by job involvement, and perceived happiness to the quality of work-life was $56.9 \%$, while the remaining $43.1 \%$ was influenced by variables outside the study.

The contribution of job involvement to quality of work-life was $47.12 \%$ and the effective contribution made by perceived happiness to quality of work-life was $11.10 \%$, so it could be concluded that the job involvement variable gives a greater effective contribution to the quality of work-life compared to the perceived happiness variable.[]

\section{References}

Azwar, S. (2012). Reliabilitas dan validitas. Yogyakarta: Pustaka Pelajar.

Azwar, S. (2013). Penyusunan skala psikologi. Yogyakarta: Pustaka Pelajar.

Badan Pusat Statistik. (2017). Tingkat Pengangguran Terbuka (TPT) sebesar 5,33 persen. Retrieved from https://www.bps.go.id/pressrelease/2017/05/05/1376/tingkat-pengangguran-terbuka --tpt--sebesar-5-33-persen.html

Bender, K. A., \& Roche, K. (2013). Educational mismatch and self-employment. Economics of Education Review, 34, 85-95. https://doi.org/10.1016/j.econedurev.2013.01.010

Cascio, W. F. (1982). Applied psychology in personnel management. Reston: Reston Publishing.

Comyn, P. (2017). The ILO global product on jobs and skills mismatch. International Labour Organization (ILO).

Danna, K., \& Griffin, R. W. (1999). Health and well-being in the workplace: A review and synthesis of the literature. Journal of Management, 25(3), 357-384. https://doi.org/10.1177/ 014920639902500305 
Dasgupta, M. (2010). Emotional intelligence emerging as a significant tool for female information technology professionals in managing role conflict and enhancing quality of work-life and happiness. Asian Journal of Management Research.

Easton, S., \& Laar, D. Van. (2013). QoWL (Quality of Working Life) - what, how, and why? Psychology Research, 3(10), 596-605. Retrieved from http://www.davidpublishing.com/show.html? 14709

Fuadi, M. (2013). Pengaruh kompensasi, lingkungan kerja dan keterlibatan kerja terhadap kualitas kehidupan kerja pegawai pada dinas pendidikan provinsi Aceh. Jurnal Manajemen Pascasarjana Universitas Syiah Kuala, 2(1).

Kaur, A. (2016). Quality of work life. International Journal of Engineering Science and Computing, 6(7), 8305-8311.

Lau, R. S. M., \& May, B. E. (1998). A win-win paradigm for quality of work life and business performance. Human Resource Development Quarterly, 9(3), 211-226. https://doi.org/10.1002/ hrdq.3920090302

Lodahl, T. M., \& Kejnar, M. (1965). The definition and measurement of job involvement. Journal of Applied Psychology, 49(1), 24-33. https://doi.org/10.1037/h0021692

Lyubomirsky, S., \& Lepper, H. S. (1999). A measure of subjective happiness: Preliminary reliability and construct validation. Social Indicators Research, 46(2), 137-155. https://doi.org/10.1023/ A:1006824100041

Mardiana, C. F. (2017, August 29). 63\% orang Indonesia bekerja tak sesuai jurusan. DetikFinance. Retrieved from https://finance.detik.com/berita-ekonomi-bisnis/d-3620313/63-orangindonesia-bekerja-tak-sesuai-jurusan

Oshagbemi, T. (1999). Overall job satisfaction: How good are single versus multiple-item measures? Journal of Managerial Psychology, 14(5), 388-403. https://doi.org/10.1108/ 02683949910277148

Pettijohn, T. F., \& Pettijohn, T. F. (1996). Perceived happiness of college students measured by Maslow's hierarchy of needs. Psychological Reports, 79(3), 759-762. https://doi.org/10.2466/ pr0.1996.79.3.759

Priyatno. (2012). Belajar cepat olah data statistik dengan SPSS. Yogyakarta: CV Andi Offset.

Santoso, S. (2014). Statistik multivariat, edisi revisi, konsep dan aplikasi dengan SPSS. Jakarta: PT. Elex Media Komputindo.

Seligman, M. (2005). Authentic happiness: Using the new positive psychology to your potential for lasting fulfilment. Bandung: PT. Mizan Pustaka.

Warr, P., Cook, J., \& Wall, T. (1979). Scales for the measurement of some work attitudes and aspects of psychological well-being. Journal of Occupational Psychology, 52(2), 129-148. https://doi.org/ 10.1111/j.2044-8325.1979.tb00448.x 